\title{
Modeliranje kreditnog rizika jedinica lokalne samouprave u Republici Hrvatskoj
}

Posedel, Petra; Primorac, Marko

Source / Izvornik: Odabrani prijevodi, 2012, 3, 1 - 22

Journal article, Published version

Rad u časopisu, Objavljena verzija rada (izdavačev PDF)

https://doi.org/10.3326/op.12

Permanent link / Trajna poveznica: https://urn.nsk.hr/urn:nbn:hr:242:825520

Rights / Prava: Attribution-NonCommercial-NoDerivatives 4.0 International/ImenovanjeNekomercijalno-Bez prerada 4.0 međunarodna

Download date / Datum preuzimanja: 2023-04-26

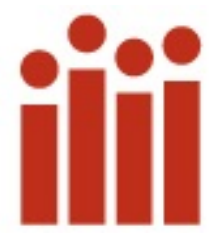

Institute of Public Finance Repository

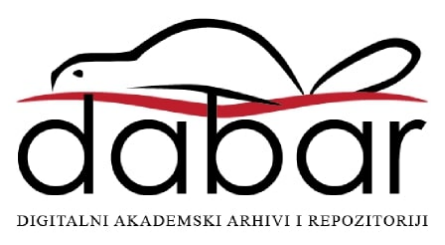




\section{ODABRANI PRIJEVODI}

\author{
ISSN $1847-7445$
}

\section{BR. I2/I2}

\section{MODELIRANJE KREDITNOG RIZIKA JEDINICA LOKALNE SAMOUPRAVE U REPUBLICI HRVATSKOJ}

\author{
DR. SC. PETRA POSEDEL ${ }^{*} \quad$ Članak $^{* *}$ \\ MA MARKO PRIMORAC* JEL: H74, GI2 \\ UDK: $342.9: 352(497.5)$ \\ DOI: $10.3326 /$ op.12
}

\begin{abstract}
SAŽETAK
Cilj rada je utorditi moguće pokazatelje koji utječu na kreditni rizik lokalnih jedinica te istražiti njihov utjecaj na vjerojatnost neplaćanja (kreditni rizik) jedinica lokalne samouprave u Hrvatskoj. U Hrvatskoj nije uspostavljen sustav procjene kreditnog rizika jedinica lokalne samouprave zbog čega se javljaju mnogi praktični problemi u zaduživanju lokalnih jedinica. $S$ obzirom na specifičnu prirodu poslovanja lokalnih jedinica i zakonodavni okvir koji ne dopušta provođenje stečajnog postupka nad jedinicama lokalne samouprave u Hrvatskoj, konvencionalne metode procjene kreditnog rizika nisu primjenjive, a skup standardnih potencijalnih odrednica kreditnog rizika treba proširiti novim pokazateljima. U radu se tako - uz uobičajene odrednice kreditnog rizika primjenom Tobit modela testira hipoteza o utjecaju političkih čimbenika na kreditni rizik jedinica lokalne samouprave u Hrvatskoj. Rezultati ekonometrijske analize ukazuju da na kreditni rizik jedinica lokalne samouprave u Hrvatskoj utječe politička struktura izvršne vlasti, udio prihoda od poreza i prireza porezu na dohodak u prihodima poslovanja, omjer neto operativnog salda, neto financijskih obveza i izravnog duga i prihoda poslovanja, kao i odnos otplate duga i gotovine te izravnog duga i prihoda poslovanja.
\end{abstract}

Ključne riječi: kreditni rizik, jedinice lokalne samouprave, Tobit model, Hrvatska

\footnotetext{
*Autori zahvaljuju trojici anonimnih recenzenata na korisnim komentarima i sugestijama.

** Primljeno: I. lipnja 2OII.

Prihvaćeno: 7. prosinca 2011.

Rad je prijavljen za godišnju nagradu Zaklade prof. dr. Marijan Hanžeković u 2oII. godini.
}

Petra POSEDEL

Zagrebačka škola ekonomije i menadžmenta, Jordanovac IIo, IOooo Zagreb

e-mail: pposedel@zsem.hr

Marko PRIMORAC

Ekonomski fakultet u Zagrebu, Trg J. F. Kennedya 6, Ioooo Zagreb

e-mail: mprimorac@efzg.hr 


\section{UvOD}

Jesu li se jedinice lokalne samouprave ${ }^{\mathrm{I}}$ sposobne zadužiti? Za odgovor na to pitanje potrebno je uspostaviti sustav procjene kreditnog rizika lokalnih jedinica. O važnosti ovog problema dovoljno govore brojna teorijska i empirijska istraživanja. Mjerodavna državna tijela - prije davanja jamstava za zaduživanje lokalnim jedinicama - trebaju procijeniti kreditni rizik lokalnih jedinica. U pojedinim je zemljama (primjerice u Meksiku) sustav procjene kreditnog rizika postao sastavni dio institucionalnog okvira za zaduživanje lokalnih jedinica (Liu i Tan, 2009). Nekoliko je mogućih čimbenika koji doprinose važnosti procjene kreditnog rizika lokalnih jedinica. Uz fiskalnu decentralizaciju, oni uključuju i razvoj tržišno usmjerene politike zaduživanja, želju za povećanjem kredibiliteta, potragu za boljim uvjetima zaduživanja i jačanje zakonodavnog okvira Gaillard (2009)².

U Hrvatskoj ne postoji sustav procjene kreditnog rizika lokalnih jedinica. Zbog nepostojanja informacija o kreditnom riziku lokalnih jedinica teško je prepoznati uspješne lokalne jedinice te ih istaknuti kao dobre primjere (Bajo i Primorac, 2009), a neposredno je otežan posao Ministarstvu financija u procesu dodjele suglasnosti i jamstava za zaduživanje lokalnim jedinicama. Jedan od razloga nepostojanja procjene kreditnog rizika je slabo i nerazvijeno tržište lokalnih obveznica, pri čemu su lokalne jedinice sklonije kreditnim zaduženjima uz državno jamstvo. Često se površno smatra kako su lokalne jedinice nerizični dužnici jer država daje jamstvo za njihovo zaduživanje. Međutim, postojanje dospjelih nepodmirenih obveza lokalnih jedinica ukazuje na činjenicu kako one nisu sasvim ažurne u izvršavanju svojih obveza. Iako su potraživanja vjerovnika relativno sigurna, upitno je vrijeme njihove naplate. Pošto se kreditni rizik odnosi na rizik neispunjavanja obveza po dospijeću i u potpunosti, svako prekoračenje datuma dospijeća može se okarakterizirati kao ostvarenje kreditnog rizika. Hrvatski Zakon o stečaju (NN 44/96, čl.3, st.2) ne dopušta provođenje stečajnog postupka nad lokalnim jedinicama premda su učestale blokade računa pojedinih lokalnih jedinica zbog neispunjenja financijskih obveza. Iako se kredibilitet financijskog poslovanja lokalnih jedinica u Hrvatskoj znatno smanjio pod utjecajem financijske krize, insolventnost pojedinih gradova i prije krize potvrđuje kako je ovaj problem prisutan (u većoj ili manjoj mjeri) neovisno o ekonomskim okolnostima. Uzroci blokade računa hrvatskih gradova od 2005. do 20II. godine uključuju: nepodmirene obveze prema dobavljačima (Ploče i Biograd), potraživanja banaka po danim kreditima (Zlatar), protestirana jamstva (Trogir), potraživanja Ministarstva financija za povrat poreza građana (Osijek), potraživanja vlasnika za oduzeta zemljišta (Dubrovnik) i sl. Grad Slavonski Brod pokazuje da insolventnost lokalnih jedinica može imati i

\footnotetext{
${ }^{\mathrm{I}} \mathrm{U}$ nastavku teksta će se radi jednostavnosti umjesto pojma jedinica lokalne samouprave uglavnom koristiti pojam lokalna jedinica. ${ }^{2}$ Osim zakonodavnog okvira koji je usmjeren na uspostavljanje fiskalne discipline na lokalnoj razini, sve većoj važnosti procjene kreditnog rizika lokalnih jedinica u posljednje vrijeme doprinosi i regulacija bankovnog sustava. Iako već inicijalni sporazum o kapitalu (Basel I) iz I988. određuje osnovne parametre upravljanja rizicima i adekvatnosti kapitala, regulatorni okvir Basel II daje detaljne smjernice za izračun kapitalnih zahtjeva (posebno za kreditni i operativni rizik). Prvi stup regulatornog okvira Basel II (Minimalni kapitalni zahtjevi) određuje pravila za izračunavanje kreditnog rizika kroz: (a) standardizirani pristup (engl. Standardized Approach), (b) interni sustav raspoređivanja - osnovni pristup (engl. Foundation Internal Rating Based, FIRB), i (c) interni sustav raspoređivanja - napredni pristup (engl. Advanced Internal Rating Based, AIRB). Svaki od ovih pristupa, u konačnici, služi za izračunavanje kapitalnih zahtjeva (kapitala kojeg su banke dužne izdvojiti za pokrivanje rizika izloženosti pojedinim plasmanima). U osnovi izračuna kapitalnih zahtjeva je vjerojatnost neplaćanja (kreditni rizik) svakog pojedinog plasmana/dužnika. Sukladno tome, banke koje - na bilo koji način - kreditiraju lokalne jedinice, trebale bi (u kontekstu izračuna kapitalnih zahtjeva) na raspolaganju imati informacije o kreditnom riziku lokalnih jedinica.
} 
znatno ozbiljnije posljedice od blokade računa. Imovina Grada je zbog neispunjenja financijskih obveza bila na dražbi.

Kreditni rizik lokalnih jedinica u pravilu nije viši od kreditnog rizika države u kojoj se one nalaze (engl. sovereign ceiling). Imajući u vidu da središnja država uglavnom jamči izvršenje obveza lokalnih jedinica pri zaduživanju, kreditni rizik ne bi trebao biti ni znatno niži. Međutim, različit status lokalnih jedinica unutar neke države, razlike $\mathrm{u}$ fiskalnim kapacitetima, broju stanovnika te nedovoljno definirana pravila raspodjele poreznih prihoda i brojne druge činjenice ukazuju na znatne razlike u njihovoj financijskoj stabilnosti (Carnevale i Coulton, 2006).

Cilj je rada utvrditi pokazatelje koji u najvećoj mjeri određuju kreditni rizik lokalnih jedinica te istražiti njihov utjecaj na kreditni rizik lokalnih jedinica u Hrvatskoj. U radu se, dakle, testira hipoteza o utjecaju različitih pokazatelja na kreditni rizik lokalnih jedinica u Hrvatskoj. Drugi dio rada pruža teorijski okvir za procjenu kreditnog rizika te obrazloženje odabira odgovarajuće metode procjene. U trećem dijelu opisuju se varijable koje bi mogle utjecati na kreditni rizik lokalnih jedinica. U četvrtom dijelu je opis modela i rezultati ekonometrijske analize. U tom se dijelu procjenjuju i parametri modela te uspoređuju modelom predviđene i procijenjene (stvarne) vrijednosti kreditnog rizika. U petom dijelu su izneseni zaključci rada i preporuke za daljnja istraživanja.

\section{TEORIJSKI OKVIR}

Procjena kreditnog rizika u znanstvenoj i stručnoj literaturi ozbiljnije se pojavljuje već početkom druge polovice prošlog stoljeća. Unatoč znanstvenim dostignućima, do danas nije postignut konsenzus o najboljoj metodologiji, ni o skupu pokazatelja (ulaznih varijabli) koje valja koristiti za procjenu kreditnog rizika pojedine skupine dužnika.

U prvim radovima o procjenama kreditnog rizika autori su pokušavali predvidjeti stečaj dužnika korištenjem analize diskriminante (Altman, 1968; Carleton i Lerner 1969, te nešto kasnije Raman, 1981) i regresijske analize (Hastie, 1972; Ohlson, 1980; i Zmijewski, 1984; Lewis et al., 1988; i Anderson, 2007). Nešto ranije, Fisher (1959) koristi regresijsku analizu za istraživanje determinanti premija rizika na korporacijske obveznice. Henley i Hand (1996) koriste klaster analizu (metodu najbližih susjeda), a u novije vrijeme koriste se i suvremeniji pristupi procjeni rizika primjenom neuronskih mreža (Odom i Sharda, 1990) i genetskog algoritma (Shin i Han, 1999; Shin i Lee, 2002; Ong et al., 2005) te potpornih vektora (Zan Huang et al., 2004) i neizrazite (engl. fuzzy) logike (Wang, Wang i Lai, 2005; te Hájek i Olej, 2007).

Prvi radovi javljaju se sedamdesetih i osamdesetih godina prošlog stoljeća. Carleton i Lerner (1969) već krajem šezdesetih godina skoring modelom ispituju utjecaj institucionalnog ustroja, stanovništva, različitih pokazatelja zaduženosti, i stope prikupljanja poreza lokalnih jedinica na njihov kreditni rejting. Hastie (1972) proučava utjecaj nešto većeg skupa nezavisnih varijabli (zaduženost, ekonomska diverzifikacija, prirast stanovništva, itd.) na prinose municipalnih obveznica. Wallace (198I) istražuje povezanost računovodstvenih pokazatelja s troškovima zaduživanja; Ingram i Copeland (1982) proširuju 
Wallace (198I) korištenjem drugih varijabli; a Benson et al. (1984) ispituje povezanost državne regulacije računovodstvenih postupaka na troškove zaduživanja lokalnih jedinica. Da su karakteristike poslovanja lokalnih jedinica važna odrednica kreditnog rizika, a posredno i prinosa lokalnih obveznica potvrđuje i Capeci (199I, 1994). Velik broj recentnih istraživanja Gaillard (2009), Lipnick (1999), Liu i Tan (2009) potvrdio je utjecaj različitih pokazatelja lokalnih jedinica na njihov kreditni rizik.

\section{TABLICA I.}

Tradicionalni pristupi procjeni kreditnog rizika

\begin{tabular}{|c|c|}
\hline Metoda & Autori \\
\hline Analiza diskriminante & Altman (1968), Carleton i Lerner (1969), Raman (198I) \\
\hline Linearna regresija (OLS) & Hastie (1972), West (1970), Fisher (1959) \\
\hline Logit & Ohlson (1980), Lewis, Patton i Green (I988), Ederington (1985) \\
\hline Probit & Zmijewski (1984), Jackson i Boyd (1988), Gentry, Whitford i Newhold (1988) \\
\hline Klaster analiza & Henley i Hand (1996), Chatterjee i Barcun (1970), Hájek i Olej (2006) \\
\hline Genetski algoritam & Shin i Han (1999), Shin i Lee (2002), Ong et al. (2005) \\
\hline Neuronske mreže & Odom i Sharda (1990), Piramuthu (1999), Baesens et al. (2003) \\
\hline Metoda potpornih vektora & Zan Huang et al. (2004), Min i Lee (2005) \\
\hline $\begin{array}{l}\text { Neizrazita logika } \\
\text { (engl. fuzzy logic) }\end{array}$ & Wang, Wang i Lai (2005), Hájek i Olej (2007) \\
\hline
\end{tabular}

Napomena: Praktični problemi u procesu procjene rizika $i$ kontinuiran napredak u istraživanju ovog područja rezultiraju neprestanom pojavom novih, suvremenijih modela procjene među koje spadaju strukturni modeli (KMV Credit Monitor i hibridni Moody's Risk Calc), intensity-based ili reduced form modeli (KPMG Loan Analysis System i Kamakura Risk Manager), value at risk modeli (CreditMetrics i Algorithmic Mark-to-Future) te mortality rate modeli (Credit Risk Plus).

Izvor: Sistematizacija autora.

Kreditni rizik lokalnih jedinica ovisi o brojnim čimbenicima koji se, načelno, mogu podijeliti u nekoliko skupina. To su: institucionalni okvir, ekonomska struktura, upravljanje i administracija, financije i proračun, te likvidnost i dugoročne obveze (Gaillard, 2009; Lipnick, 1999; Liu i Tan, 2009). Na temelju analize pokazatelja grupiranih u pojedine skupine moguće je kvantificirati njihov utjecaj na kreditni rizik lokalnih jedinica. Iako su brojna znanstvena istraživanja pokušavala odgovoriti na pitanje koje varijable u najvećoj mjeri utječu na kreditni rizik lokalnih jedinica, najpotpuniji popis potencijalnih čimbenika iznjedrila je ipak praktična provedba procesa procjene kreditnog rizika. Agencije za procjenu kreditnog rejtinga Standard i Poor's, Moody's i Fitch Ratings sistematizirale su popis pokazatelja koje koriste prilikom procjene kreditnog rejtinga lokalnih jedinica (prilog I.). Velik dio odrednica kreditnog rizika odražava upravo specifičnosti pojedinih zemalja i njihovih institucionalnih okvira pa još uvijek ne postoje jedinstveni, općeprihvaćeni kriteriji procjene.

U ovom će se radu, uz uobičajene pokazatelje kreditnog rizika, testirati utjecaj jedne od takvih specifičnih - varijabli na kreditni rizik lokalnih jedinica u Hrvatskoj. Općenito, smatra se da je lokalna jedinica manje rizična ukoliko joj je udio vlastitih prihoda u ukupnim prihodima veći. S tim u skladu, lokalne jedinice koje se većim dijelom oslanjaju na nestabilne izvore prihoda (sredstva pomoći iz državnog proračuna) rizičnije su. Problem raspodjele sredstava pomoći lokalnim jedinicama postaje posebno složen uzmu li se u obzir i njegovi politički aspekti. Brojna istraživanja s kraja prošlog stoljeća bavila su se međuovisnošću političke ekonomije i raspodjele sredstava pomoći. S vremenom su se tako razvile i dvije prevladavajuće teorije. Cox i McCubbins (1986), utemeljitelji jedne od teorija, smatraju 
kako vladajuća struktura u raspodjeli sredstava pomoći favorizira one lokalne jedinice u kojima ima političku podršku (lokalne jedinice s politički kompatibilnom izvršnom vlašću). Alternativna teorija, čiji su glavni zastupnici Lindbeck i Weibull (1987) te Dixit i Londregan (1998) navodi da se sredstva iz državnog proračuna dodjeljuju lokalnim jedinicama u kojima su preferencije glasača promjenjive, tj. lokalnim jedinicama u kojima prevladavaju nelojalni birači (engl. swing voters). Iako još uvijek nije jasno koja je od dvije teorije točnija, pitanje učinka političkih čimbenika na raspodjelu pomoći iz državnog proračuna lokalnim jedinicama predstavlja znanstveni problem iz područja političke ekonomije. U ovom istraživanju nastoji se utvrditi postoji li utjecaj političkih čimbenika na kreditni rizik lokalnih jedinica u Hrvatskoj.

\section{ODREDNICE KREDITNOG RIZIKA LOKALNIH JEDINIGA}

U Hrvatskoj ne postoji instrument stečaja lokalnih jedinica, kao što je to slučaj u nekim zemljama (primjerice $\mathrm{u}$ Mađarskoj), zbog čega standardna procjena kreditnog rizika na temelju povijesnih vrijednosti stečaja koji se ili ostvario ili nije (binarna varijabla - dihotomna) nije moguća. Stoga se kreditni rizik mora aproksimirati na alternativni način. Kreditni rizik može se okarakterizirati kao rizik neispunjenja dužnikovih obveza na vrijeme i u potpunosti. Taj se rizik, dakle, može aproksimirati udjelom dospjelih nepodmirenih obveza nastalih unutar godine dana u ukupnim obvezama dospjelim u toj godini. Sukladno tome, kreditni rizik lokalnih jedinica u Hrvatskoj može se aproksimirati (engl. default proxy) na temelju omjera dospjelih nepodmirenih obveza u određenoj godini i ukupnih rashoda ${ }^{3}$ lokalnih jedinica nastalih $\mathrm{u}$ istom razdoblju.

Kreditni rizik lokalnih jedinica - aproksimiran na gore opisan način - kretao se 20o8. u rasponu od o\% do 70,27\% (tablica 2). Koeficijent asimetrije $\left(\alpha_{3}\right)$ ukazuje na pozitivno asimetričnu distribuciju frekvencija, što je očekivano s obzirom na prirodu statističkog skupa. Naime, lokalne jedinice su niskorizični subjekti pa se koncentracija empirijskih vrijednosti smanjuje porastom kreditnog rizika. Srednja vrijednost statističkog skupa prikazuje prosječnu vrijednost aproksimiranog kreditnog rizika lokalnih jedinica od 7,or\%.

\section{TABLIGA2.}

Deskriptivna statistika aproksimiranog kreditnog rizika za 2008.

$\begin{array}{cccccccc}- & x_{\text {min }} & \boldsymbol{x}_{\text {max }} & \boldsymbol{\sigma} & \boldsymbol{\sigma}^{2} & \boldsymbol{\alpha}_{3} & \boldsymbol{\alpha}_{4} & \mathbf{N} \\ \text { 0,0701 } & \text { 0,0000 } & 0,7027 & 0,0952 & \text { 0,0091 } & 2,1864 & 6,8494 & 556\end{array}$

Izvor: Izračun autora na temelju financijskih izvještaja lokalnih jedinica za 2008.

Podaci za eksplanatorne varijable odnose se na 556 općina i gradova u Hrvatskoj, a izračunati su za 2008. na temelju financijskih izvješća lokalnih jedinica, Državnog zavoda za statistiku (gospodarski i demografski podaci) te Državnog izbornog povjerenstva (podaci o izborima članova predstavničkih

\footnotetext{
${ }^{3} \mathrm{U}$ skladu s modificiranim računovodstvenim načelom nastanka događaja koje se primjenjuje u Hrvatskoj (ne iskazuje se rashod amortizacije dugotrajne nefinancijske imovine, a rashodi se priznaju na temelju nastanka poslovnog događaja neovisno o plaćanju) ukupne obveze dospjele unutar godine dana mogu se (za potrebe analize) poistovjetiti s ukupnim rashodima i izdacima te godine.
} 
tijela jedinica lokalne i područne samouprave). Zavisna varijabla default_proxy izračunata je kao omjer dospjelih nepodmirenih obveza lokalnih jedinica $\mathrm{u}$ ukupno dospjelim obvezama $\mathrm{u}$ promatranom razdoblju. Mnogo čimbenika potencijalno utječe na varijablu default_proxy i kreditni rizik lokalnih jedinica. S ciljem identificiranja glavnih odrednica kreditnog rizika, analiziran je skup od 27 nezavisnih varijabli (prilog 2, tablica A4), koji je metodom indukcije sveden na II najrelevantnijih ${ }^{4}$ nezavisnih varijabli (tablica 3).

\section{TABLICA 3.}

Specifikacija odabranih nezavisnih varijabli

\begin{tabular}{|c|c|c|}
\hline Varijabla & Opis varijable & Očekivani utjecaj \\
\hline status & $\begin{array}{l}\text { Binarna varijabla koja poprima vrijednost i ukoliko lokalna jedinica } \\
\text { ima status grada, a o ukoliko ima status općine }\end{array}$ & Negativan \\
\hline politika & $\begin{array}{l}\text { Binarna varijabla koja poprima vrijednost i ukoliko je ista politička } \\
\text { stranka na vlasti u državi i lokalnoj jedinici, u protivnom je o }\end{array}$ & Negativan \\
\hline$i z v o z \_B D P$ & Omjer vrijednosti izvoza i BDP-a lokalne jedinice & Negativan \\
\hline lst_nst & $\begin{array}{l}\text { Omjer broja stanovnika lokalne jedinice i ukupnog broja } \\
\text { stanovnika Hrvatske }\end{array}$ & Negativan \\
\hline une_lst & Udio nezaposlenih stanovnika u ukupnom stanovništvu lokalne jedinice & Pozitivan \\
\hline pdoh_tp & Udio prihoda od poreza na dohodak $u$ prihodima poslovanja & Negativan \\
\hline nos_tp & Omjer neto operativnog salda i prihoda poslovanja & Negativan \\
\hline got_tr & Omjer gotovine i rashoda poslovanja & Negativan \\
\hline$o d_{g} g o t$ & Omjer otplate duga i gotovine & Pozitivan \\
\hline$i d \_t p$ & Omjer izravnog duga i prihoda poslovanja & Pozitivan \\
\hline nfl_tp & Omjer neto financijskih obveza i prihoda poslovanja & Pozitivan \\
\hline
\end{tabular}

Napomena: Vrijednost BDP-a aproksimirana je na temelju broja stanovnika lokalne jedinice i BDP per capita županije u kojoj se lokalna jedinica nalazi. Izvor: Prikaz autora.

Institucionalni okvir lokalne samouprave u Hrvatskoj razlikuje lokalne jedinice koje imaju status općine i one koje imaju status grada. Stoga postoji opravdana sumnja da sam status (općine ili grada) $a$ priori određuje veći/manji kreditni rizik lokalne jedinice. Isto tako, pretpostavlja se da u tranzicijskim zemljama politika još uvijek ima značajnu ulogu u financiranju lokalnih jedinica. Sukladno političkim kriterijima podobne lokalne jedinice mogu biti povlaštene u sustavu financiranja čime se njihov financijski položaj (a posredno i kreditni rizik) može poboljšati na štetu ostalih. Varijable vezane uz demografske pokazatelje (lst_nst i une_lst) interesantne su zbog toga što se lokalne jedinice u Hrvatskoj uglavnom oslanjaju na prihode od zajedničkih poreza (posebice poreza na dohodak) koji je u izravnoj vezi s demografskom strukturom lokalnih jedinica (brojem i strukturom zaposlenih), dok udio izvoza u BDP-u (izvoz_BDP) odražava gospodarsku razvijenost lokalne jedinice. Udio poreza na dohodak u prihodima poslovanja ( $p d o h \_t p$ ) pokazuje samodostatnost $\mathrm{u}$ financiranju lokalne jedinice (pošto je lokalna jedinica s većim udjelom manje ovisna o neizvjesnim sredstvima pomoći iz državnog proračuna). Ostali pokazatelji izvedeni iz prihoda poslovanja (nos_tp, id_tp i $n f l \_t p$ ) pokazuju uglavnom različite aspekte sposobnosti financiranja obveza i trebali bi u najvećoj mjeri određivati kreditni rizik

\footnotetext{
${ }^{4}$ Izračunom vrijednosti pokazatelja iz inicijalnog skupa (prilog 2) uočeno je kako (zbog dobivenih vrijednosti) određeni pokazatelji ne bi bili sasvim relevantni za procjenu kreditnog rizika (npr. brojnik ili nazivnik u velikom broju slučajeva je o). Isto tako, vjerojatno zbog nepostojanja točnih podataka o BDP-u lokalnih jedinica i oslanjanju na procjene, pokazatelji utemeljeni na lokalnom BDP-u su se, primjerice, pokazali manje relevantnima.
} 
lokalnih jedinica. Konačno, pokazatelji likvidnosti (got_tr i od_got) mjere sposobnost financiranja rashoda poslovanja i otplate duga najlikvidnijom imovinom - novcem.

\section{TABLICA 4.}

Deskriptivna statistika za 556 lokalnih jedinica u 2008.

\begin{tabular}{|c|c|c|c|c|c|}
\hline Varijabla & Srednja vrijednost & Medijan & Maksimum & Minimum & Std. dev. \\
\hline default_proxy & 0,070I & O,03I4 & 0,7027 & 0,000 & 0,0952 \\
\hline status & 0,2284 & O,ooo & I,OOO & 0,000 & $0,42 \mathrm{O} 2$ \\
\hline politika & 0,4532 & 0,000 & $\mathrm{I}, \mathrm{OOO}$ & o,ooo & 0,4983 \\
\hline$i z v o z \_B D P$ & O,IO94 & O,OII2 & 3,4545 & o,ooo & 0,2883 \\
\hline lst_nst & 0,0018 & 0,0007 & O,I779 & 0,000 & 0,008I \\
\hline une_lst & 0,0605 & O,0537 & 0,2228 & 0,0027 & 0,0337 \\
\hline$p d o h \_t p$ & 0,3908 & 0,3895 & 0,7748 & 0,0278 & O,I549 \\
\hline nos_tp & $-0,0393$ & $-0,026 \mathrm{I}$ & $\mathrm{I}, 8 \mathrm{I} 6 \mathrm{I}$ & $-0,9934$ & 0,2153 \\
\hline got_tr & 0,2613 & $\mathrm{O}, \mathrm{I} 642$ & 2,4765 & $\mathrm{O}, \mathrm{OOO} 2$ & 0,3139 \\
\hline od_got & I,3419 & o,ooo & I,OOO3 & o,ooo & $7,38 \mathrm{OI}$ \\
\hline id_tp & 0,0842 & O,OOO & $\mathrm{I}, 23 \mathrm{I} 8$ & 0,000 & O,I685 \\
\hline$n f l \_t p$ & $-0,1313$ & $-0, \operatorname{IO} 84$ & $\mathrm{I}, \mathrm{I} 426$ & $-I, 8944$ & 0,2755 \\
\hline
\end{tabular}

Izvor: Izračun autora.

Koeficijenti korelacije zavisne varijable i jedanaest nezavisnih varijabli (potencijalnih odrednica kreditnog rizika lokalnih jedinica) prikazani su u tablici A5 (prilog 2). Predznaci koeficijenata korelacije uglavnom su u skladu s očekivanim utjecajem promatranih odrednica na kreditni rizik lokalnih jedinica - osim za pokazatelj političke strukture izvršne vlasti. Očekivan negativni utjecaj političke kompatibilnosti izvršne vlasti na lokalnoj i državnoj razini bio je utemeljen na očekivanju kako vladajuća struktura u raspodjeli sredstava pomoći iz državnog proračuna favorizira lokalne jedinice $u$ kojima ima političku potporu, čime bi - u konačnici - financijska sposobnost takvih lokalnih jedinica trebala biti veća (kreditni rizik trebao bi biti manji). Matrica korelacije ovu pretpostavku djelomično i potvrđuje s obzirom na negativnu korelaciju varijabli politika i pdoh_tp koja ukazuje na činjenicu da se lokalnim jedinicama čija je izvršna vlast politički kompatibilna s državnom izvršnom vlašću vjerojatno češće upućuju sredstva pomoći iz državnog proračuna pa je udio prihoda od poreza na dohodak u prihodima poslovanja manji. Međutim, razlozi pozitivnog utjecaja političke kompatibilnosti izvršne vlasti na lokalnoj i državnoj razini na kreditni rizik lokalnih jedinica ostaju nerazjašnjeni. Jedan od razloga može biti tolerantniji pristup financijskoj neažurnosti „podobnih“ lokalnih jedinica zbog političke protekcije, a drugi može biti povezan s rashodnom stranom njihovog proračuna koja je neumjerena zbog prevelikih zahtjeva. 


\section{MODEL PROGJENE KREDITNOG RIZIKA LOKALNIH JEDINICA}

Za modeliranje kreditnog rizika lokalnih jedinica koristi se niz statističkih i ne-statističkih alata čija primjenjivost ovisi o skupu podataka. Pošto zavisnu varijablu od interesa (stečaj lokalnih jedinica) ne opažamo direktno (iz ranije navedenih razloga), vrijednost latentne varijable od interesa (default_proxy $\left.y^{5}\right)$ za netrivijalni je dio uzorka jednaka nuli (23.56\%), a istovremeno je neprekidno distribuirana unutar intervala [o,1]. Zbog karakterističnog financijskog poslovanja, ali i statusa lokalnih jedinica u javnom sektoru, njihov kreditni rizik očekivano je relativno nizak pa ne postoji niti jedna lokalna jedinica čija je vrijednost aproksimiranog kreditnog rizika jednaka I. Stoga se za analizu kreditnog rizika lokalnih jedinica koristi cenzurirani regresijski model - Tobit model (Greene, 2008; Wooldridge, 2006).

Kreditni rizik lokalnih jedinica $Y$ neprekidna je slučajna varijabla koja poprima pozitivne vrijednosti i može biti nula s pozitivnom vjerojatnosti. Nadalje, izračunata aproksimacija kreditnog rizika lokane jedinice (default_proxy) je latentna varijabla u modelu. Teorijski je opravdana i ima za cilj uspostavljanje osnovnih kriterija za određivanje potpunog ostvarenja rizika neplaćanja (kojeg bi se moglo poistovjetiti sa stečajem lokalnih jedinica). Na taj bi se način s vremenom omogućila zamjena neprekidno distribuirane varijable aproksimacija kreditnog rizika binarnom varijablom koja bi označavala krajnje ostvarenje rizika neplaćanja koji se ili dogodio (I) ili nije (o).

U slučajevima kada je varijabla $Y$ cenzurirana (ograničena), vrijednosti $u$ određenom rasponu transformiraju se $u$ jednu vrijednost. U slučaju predmetnog istraživanja zavisna varijabla $Y$ cenzurirana je u o. Ukoliko se latentna varijabla - default_proxy - označi s $Y^{*}$, tada je opažena varijabla $Y$ jednaka latentnoj varijabli u slučaju kada je default_proxy>o. Potrebno je napomenuti da zbog (teorijski opravdane) niske vrijednosti kreditnog rizika lokalnih jedinica, u uzorku nema opaženih vrijednosti varijable default_proxy=I pa zavisna varijabla u modelu nije cenzurirana gornjom vrijednosti I.

\section{I. OPIS MODELA}

Pretpostavimo da za svako opažanje $Y$ postoji latentna varijabla $Y^{*}$ koja je opisana sljedećim regresijskim modelom:

$$
Y_{i}^{*}=\beta^{\prime} X_{i}+\varepsilon_{i}, i=1, \ldots, 556,
$$

pri čemu su $\beta \leqslant \beta_{0}, \beta_{I}, \ldots, \beta_{I I}$ - nepoznati parametri modela, $X_{i}=\left(1, X_{1}, X_{2}, \ldots, X_{11}\right)_{i}$, a varijable $X_{1}, X_{2}, \ldots, X_{11}$ predstavljaju redom status (općina ili grad), politika (binarna varijabla koja poprima vrijednost I u slučaju da je politička struktura izvršne vlasti na državnoj i lokalnoj razini kompatibilna ista politička stranka, a u protivnom o), udio lokalnog izvoza u lokalnom bruto domaćem proizvodu (izvoz_bdp), udio lokalnog stanovništva u ukupnom stanovništvu Republike Hrvatske (lst_nst), udio nezaposlenih u ukupnom lokalnom stanovništvu (une_lst), udio prihoda od poreza na dohodak $\mathrm{u}$ prihodima poslovanja ( $p d o h \_t p$ ), udio neto operativnog salda u prihodima poslovanja (nos_tp), udio

\footnotetext{
${ }^{5}$ Ponekad se u tekstu koristi i izraz aproksimirani kreditni rizik ili aproksimacija kreditnog rizika.
} 
gotovine $\mathrm{u}$ rashodima poslovanja (got_tr), udio otplate duga u gotovini (od_got), udio izravnog duga ${ }^{6} \mathrm{u}$ prihodima poslovanja (id_tp), udio neto financijskih obveza u prihodima poslovanja ( $\left.n f l \_t p\right)$, dok su $\varepsilon_{i}$ nezavisne, jednako distribuirane, normalne ${ }^{7}$ slučajne varijable očekivanja nula i varijance $\sigma^{2}$. Uvjetna je distribucija latentne varijable $Y^{*}$, zbog normalne distribucije grešaka $\varepsilon_{i}$, također normalna, $\mathrm{s}$ očekivanjem $E\left[Y^{*} \mid X_{i}\right]=\beta^{\prime} X_{i}$ i varijancom $\operatorname{Var}\left[Y^{*} \mid X_{i}\right]=\sigma^{2}$. Rezultati deskriptivne analize varijabli $X_{i}=\left(1, X_{1}, X_{2}, \ldots, X_{11}\right)$ za svih 556 lokalnih jedinica u Hrvatskoj prikazani su u prethodnom poglavlju (tablica 4).

Zavisna cenzurirana varijabla $Y$ - koja predstavlja kreditni rizik lokalnih jedinica - modelira se koristeći lijevo cenzurirane podatke na sljedeći način:

$$
Y_{i}=\left\{\begin{array}{ll}
0, & \text { ako je } Y_{i}^{*} \leq 0 \\
Y_{i}^{*} & \text { ako je } Y_{i}^{*}>0
\end{array} .\right.
$$

Nepoznati parametri modela $\beta$ i $\sigma$ procjenjuju se maksimizacijom funkcije vjerodostojnosti, $L\left(\beta, \sigma, \mid Y_{1}, \ldots, Y_{N}\right)=\prod_{i=1}^{N} f\left(y_{i}\right)$, odnosno funkcije log-vjerodostojnosti $\log L\left(\beta, \sigma, Y_{1}, \ldots, Y_{N}\right)$, pri čemu su $y_{1}, y_{2}, \ldots, y_{N}$ realizacije nezavisnih i jednako distribuiranih slučajnih varijabli $Y_{i}$, uz $N=556$ (ukupan broj lokalnih jedinica u Hrvatskoj), a f je funkcija gustoće svakog opažanja ograničene zavisne varijable $Y_{i}$ uzimajući u obzir da opažamo samo njezine vrijednosti veće od nule. S obzirom da vrijednosti opažene ograničene zavisne varijable ne mogu poprimiti vrijednosti manje od nule, krnja distribucija iz koje će dolaziti takve vrijednosti, odnosi se na dio neprekidne distribucije iznad nule i na funkciju vjerojatnosti diskretne varijable u nuli. Stoga je za procjenu parametara potrebno naći one vrijednosti parametara $\beta$ i $\sigma$ koje maksimiziraju sljedeću funkciju:

$$
\ln L\left(\beta, \sigma \mid Y_{1}, \ldots, Y_{N}\right)=\ln \prod_{i=1}^{N} f\left(y_{i}\right)=\sum_{i=1}^{N} \ln \left[\frac{1}{\sigma} \cdot \phi\left(\frac{y_{i}-X_{i}^{\prime} \beta}{\sigma}\right)\right] \cdot 1_{\left(y_{i}>0\right)}+\sum_{i=1}^{N} \ln \left[1-\Phi\left(\frac{X_{i}^{\prime} \beta}{\sigma}\right)\right] \cdot 1_{\left(y_{i}=0\right)}(2)
$$

pri čemu je $\phi$ standardna normalna funkcija gustoće greške, $\Phi$ je standardna normalna kumulativna funkcija distribucije greške, a $\mathrm{I}_{(Y \supset o)}$ označava indikator funkciju koja poprima vrijednost I na skupu $\{Y>O\}$, a o na skupu $\{Y=0\}$.

Granični učinci u Tobit modelu, koji predstavljaju granični učinak pojedine varijable na kreditni rizik lokalnih jedinica, nisu stoga dani vrijednostima regresijskih koeficijenata $\beta$, već izrazom (Greene, 2008; Wooldridge, 2006):

\footnotetext{
${ }^{6}$ Pojam izravni dug u tekstu označava ukupne obveze za vrijednosne papire i zajmove te ne obuhvaća potencijalne obveze koje proizlaze iz jamstava, dospjelih nepodmirenih obveza i ostalih neizravnih kategorija duga.

${ }^{7}$ U slučaju da greške nisu normalno distribuirane ili da nisu homoskedastične, procjenitelji dobiveni metodom maksimalne vjerodostojnosti neće biti konzistentni. U tom slučaju, parametri će se procijeniti metodom maksimalne logkvazivjerodostojnosti (QML procjenitelj). QML procjenitelj robustan je s obzirom na krivu pretpostavku o distribuciji zavisne varijable, konzistentan je i asimptotski normalno distribuiran. Ujedno, u slučaju heteroskedastičnosti grešaka, ista će se izravno modelirati u funkciji log-kvazivjerodostojnosti.

${ }^{8} \mathrm{I}_{(Y=0)}$ Označava indikator funkciju koja poprima vrijednost I na skupu $\{\mathrm{Y}=\mathrm{O}\}$, a o na skupu $\{\mathrm{Y}>\mathrm{O}\}$
} 


$$
\frac{\partial E\left[Y_{i} \mid X_{i}\right]}{\partial X_{j}}=\beta_{j} \Phi\left(\frac{\beta^{\prime} X_{i}}{\sigma}\right)
$$

Prema izrazu (3) slijedi da su granični učinci dani Tobit modelom jednaki produktu graničnih učinaka latentne varijable $Y^{*}$, odnosno koeficijenata $\beta$, i proporcije negraničnih opažanja u uzorku.

\subsection{REZULTATI EKONOMETRIJSKE ANALIZE}

U nastavku rada prikazuju se rezultati ekonometrijske analize dobivene maksimiziranjem funkcije logvjerodostojnosti (2) za Tobit model ${ }^{9}$. Pri procjeni Tobit modela, kao i određivanju asimptotskih svojstava dobivenih procjenitelja metodom maksimalne vjerodostojnosti, dvije su osnovne pretpostavke: greške su distribuirane u skladu s normalnom distribucijom i homoskedastične. U prvom koraku procjene parametara modela, procjenitelji istih dobiveni su maksimiziranjem funkcije log-vjerodostojnosti (ML procjenitelj). U slučaju da su pretpostavke modela zadovoljene (normalna distribuiranost i homoskedastičnost greške), ML procjenitelji su konzistentni, asimptotski normalni i efikasni. U cilju ispitivanja svojstava i kvalitete procjenitelja, testiranje pretpostavki i opće značajnosti Tobit modela izvršeno je pomoću Lagrange multiplier (LM) statistike ${ }^{\mathrm{IO}}$ za testiranje Tobit specifikacije naspram alternative modela koji nije linearan u eksplanatornim varijablama, te sadrži grešku koja može biti heteroskedastična i ne-normalno distribuirana. Test odbacuje nultu hipotezu, ukazujući da Tobit specifikacija pretpostavki modela nije prikladna za konzistentnu procjenu parametara. U cilju dobivanja konzistentnih procjenitelja, problemu heteroskedastičnosti pristupilo se direktnim modeliranjem heteroskedastičnosti eksponencijalnom funkcijom $\mathrm{u}$ funkciji log-vjerodostojnosti pomoću $\sigma_{i}=e^{\tilde{X}_{i \gamma}}$, pri čemu je $\gamma=\left(\gamma_{0}, \gamma_{1}, \ldots, \gamma_{9}\right)^{\prime}$, a $\tilde{X}_{i}=\left(1, X_{1}, X_{2}, X_{3}, X_{5}, X_{6}, X_{8}, X_{9}, X_{10}, X_{11}\right) .{ }^{\text {II }} \mathrm{U}$ slučaju da greška nije normalno distribuirana, problem je obično puno zahtjevniji za Tobit modele $u$ odnosu na linearne modele, te se u cilju njegova rješavanja predlažu alternativne procjene kao i razne metode za testiranja takvih, potencijalno krivih, specifikacija modela. Stoga će se, u drugom koraku procjene, parametri modela procijeniti maksimiziranjem funkcije log-kvazivjerodostojnosti (QML), budući da je QML procjenitelj robustan s obzirom na krivu pretpostavku o distribuciji grešaka, odnosno zavisne varijable. Na taj su način dobiveni procjenitelji modela koji su konzistentni i asimptotski normalno distribuirani. Međutim, QML procjenitelj nije asimptotski efikasan, te se za potrebe procjene varijance procjenitelja maksimalne log-vjerodostojnosti u slučajevima kada polazni model nije točno specificiran koristi Berndt-Hall-Hall-Hausman (BHHH) numerički algoritam (Greene, $2008)^{12}$.

\footnotetext{
${ }^{9} \mathrm{U}$ radu su za potrebe optimizacije korišteni, nezavisno, softveri EViews 7 i Stata Io.I.

${ }^{10}$ Kritične vrijednosti Lagrange multiplier (LM) testa određene su parametarskom bootstrap metodom. Testiranje je provedeno pomoću Box-Cox-ove transformacije zavisne varijable. Pri izračunu LM statistike kao i kritičnih vrijednosti testa korištena je programska procedura bctobit u softveru Stata Io.I.

${ }^{11}$ Varijable $\mathrm{X}_{4} \mathrm{i} \mathrm{X}_{7}$, odnosno udio lokalnog stanovništva u ukupnom stanovništvu, te udio neto operativnog salda u prihodima poslovanja, izuzete su iz modeliranja varijance budući da njihovim uključivanjem numerički algoritam za traženje maksimuma funkcije nije konvergirao. Stoga se uklonila po jedna od varijabli iz demografske strukture $\left(X_{4} \mathrm{i} X_{5}\right)$ te jedan od pokazatelja izvedenih iz prihoda poslovanja $\left(\mathrm{X}_{7}, \mathrm{X}_{\mathrm{IO}} \mathrm{i} \mathrm{X}_{\mathrm{II}}\right)$.

${ }^{12}$ Za procjenu varijance koristeći BHHH algoritam, nezavisno su korišteni softveri STATA IO.I. i EViews7, pri čemu su početni uvjeti specificirani programskom potporom i nisu modificirani u specijalnom slučaju.
} 
Tablica 5. prikazuje procijenjene parametre Tobit regresijskog modela, odgovarajuće granične učinke, te pripadajuće standardne greške. U tablici su navedeni i procjenitelji dobiveni metodom najmanjih kvadrata (OLS), unatoč njihovoj nekonzistentnosti, budući da se u empirijskim analizama pokazuje da se ML procjenitelji mogu dobiti kao omjer OLS procjenitelja i proporcije negraničnih opažanja u uzorku. ${ }^{33}$ Također, granični učinci za varijable u modelu koje se nisu pokazale statistički značajnima, isključeni su iz tablice.

\section{TABLIGA5.}

Procjena parametara, odgovarajućih graničnih učinaka za Tobit regresijski modele, te pripadajuće standardne greške

\begin{tabular}{|c|c|c|c|c|}
\hline \multirow{2}{*}{$\begin{array}{l}\text { Nezavisna } \\
\text { varijabla }\end{array}$} & \multirow{2}{*}{$\begin{array}{c}\text { Linearna regresija } \\
\text { Granični učinak }\end{array}$} & \multicolumn{3}{|c|}{ Tobit regresija } \\
\hline & & Koeficijent & Granični učinak & Heteroskedastičnost \\
\hline konstanta & $\begin{array}{r}\text { O,II34I } \\
(0,01398)\end{array}$ & $\begin{array}{r}\text { O,II945 } \\
(\mathrm{o}, \mathrm{OI} 585)\end{array}$ & - & $\begin{array}{r}-1,92925 \\
(0, I 8754)\end{array}$ \\
\hline politika & $\begin{array}{r}0,02034 \\
(0,00778)\end{array}$ & $\begin{array}{r}0,03196 \\
(0,012 \mathrm{O} 2)\end{array}$ & $\begin{array}{r}0,02072 \\
(0,00674)\end{array}$ & $\begin{array}{c}\text { O,063IO* } \\
(0,09789)\end{array}$ \\
\hline$p d o h \_t p$ & $\begin{array}{r}-0, \mathrm{II} 327 \\
(0,023 \mathrm{I})\end{array}$ & $\begin{array}{r}-0,14739 \\
(0,02726)\end{array}$ & $\begin{array}{l}-0,10986 \\
(0,02212)\end{array}$ & $\begin{array}{l}-0,793 \mathrm{O} 2 \\
(0,33 \mathrm{OII})\end{array}$ \\
\hline nos_tp & $\begin{array}{r}-\mathrm{O}, 08 \mathrm{I} 3 \\
(\mathrm{O}, \mathrm{O} 2 \mathrm{O} 3 \mathrm{I})\end{array}$ & $\begin{array}{l}-0,08130 \\
(0,02065)\end{array}$ & $\begin{array}{l}-0,06244 \\
(0,01619)\end{array}$ & - \\
\hline$n f l \_t p$ & $\begin{array}{r}0,09054 \\
(0,03276)\end{array}$ & $\begin{array}{r}\text { O,IOI4I } \\
(0,02494)\end{array}$ & $\begin{array}{r}0,06975 \\
(0,02447)\end{array}$ & $\begin{array}{r}0,34842^{*} \\
(0,41046)\end{array}$ \\
\hline od_got & $\begin{array}{r}0.00086 \\
(0,00038)\end{array}$ & $\begin{array}{r}0,00094 \\
(0,00022)\end{array}$ & $\begin{array}{r}0,00063 \\
(0,00015)\end{array}$ & $\begin{array}{l}-0,02438 \\
(0,01129)\end{array}$ \\
\hline$i d \_t p$ & $\begin{array}{r}-0.05996 * \\
(0.03710)\end{array}$ & $\begin{array}{l}-0,08766 \\
(0,03361)\end{array}$ & $\begin{array}{l}-0,05860 \\
(0,02247)\end{array}$ & $\begin{array}{l}\mathrm{O}, 02857^{*} \\
(0,52075)\end{array}$ \\
\hline status & $\begin{array}{r}-0,014052^{*} \\
(0,00885)\end{array}$ & $\begin{array}{l}-0,01432^{*} \\
\text { (o,OIO44) }\end{array}$ & - & $\begin{array}{r}-0,20347^{*} \\
(0, \mathrm{I} 4 \mathrm{I} 48)\end{array}$ \\
\hline$i z v o z \_B D P$ & $\begin{array}{r}-0,00403^{*} \\
(0,00938)\end{array}$ & $\begin{array}{r}-0,00269^{*} \\
(0,01168)\end{array}$ & - & $\begin{array}{l}-0,0813 I^{*} \\
(0,17230)\end{array}$ \\
\hline lst_nst & $\begin{array}{r}-0, I O 2167^{*} \\
(0,17733)\end{array}$ & $\begin{array}{l}\text { O,I2805* } \\
(\mathrm{O}, \mathrm{I} 2 \mathrm{I} 93)\end{array}$ & - & - \\
\hline une_lst & $\begin{array}{r}-0,07435^{*} \\
(0,10998)\end{array}$ & $\begin{array}{r}-0,09160^{*} \\
(0,13094)\end{array}$ & - & $\begin{array}{c}-\mathrm{I}, \mathrm{I} 47 \mathrm{I} 2^{*} \\
(\mathrm{I} . \mathrm{I} 84 \mathrm{II})\end{array}$ \\
\hline got_tr & $\begin{array}{l}0,04827^{*} \\
(0,03886)\end{array}$ & $\begin{array}{l}0,00958^{*} \\
(0,02480)\end{array}$ & - & $\begin{array}{l}0,45402^{*} \\
(0,27288)\end{array}$ \\
\hline $\mathrm{R}^{2}$ & $10,76 \%$ & - & - & - \\
\hline \multicolumn{2}{|c|}{ Log-kvazivjerodostojnost } & 259,14428 & - & - \\
\hline \multicolumn{5}{|c|}{$\begin{array}{l}\text { * Nisu statistički značajne za uobičajene razine značajnosti (I\%, 5\% i 10\%). } \\
\text { Izvor: Izračun autora. }\end{array}$} \\
\hline
\end{tabular}

\footnotetext{
${ }^{13}$ Navođenje rezultata dobivenih OLS procjenom s ciljem dobivanja okvirnog uvida u osjetljivost veze između kreditnog rizika lokalnih jedinica i njegovih potencijalnih determinanti, moglo bi ukazati na početnu smjernicu u pogledu istog te omogućiti praćenje eventualnih unapređenja u vidu rezultata dobivenih analizom nekog drugog modela, ali i načina procjene.
} 
varijabli $X_{i}$ (Greene, 2008). ${ }^{\mathrm{I}}$ Za diskretne eksplanatorne varijable - poput političke strukture izvršne vlasti - određivanje graničnih učinaka nije sasvim jednostavno, iako se aproksimacija pomoću faktora prilagodbe pokazala vrlo korisnom (Wooldridge, 2006). Radi određivanja graničnog učinka političke strukture izvršne vlasti - koja je u modelu zastupljena binarnom varijablom - na kreditni rizik lokalnih jedinica, očekivani kreditni rizik izračunat će se za obje moguće vrijednosti varijable politika=\{0,I\} te aritmetičke sredine preostalih signifikantnih varijabli u modelu.

Dobiveni granični učinak iznosi o,02072 i predstavlja utjecaj koji politička struktura izvršne vlasti lokalne jedinice ima na kreditni rizik - uz pretpostavku da u ostalim varijablama od interesa ne dolazi do promjene stanja ${ }^{15}$. Drugim riječima, ukoliko je ista politička stranka u izvršnoj vlasti na lokalnoj i državnoj razini, očekuje se povećanje procijenjenog kreditnog rizika od 2,I postotna boda. Pozitivna korelacija političke strukture izvršne vlasti i kreditnog rizika otkriva činjenicu da je financijsko poslovanje lokalnih jedinica u Hrvatskoj podložno političkom utjecaju, tj. da je neuredno podmirivanje financijskih obveza nekih lokalnih jedinica intenzivirano iz političkih razloga. Nejasni su razlozi zbog kojih su lokalne jedinice čija je izvršna vlast politički kompatibilna državnoj vlasti neurednije u podmirivanju financijskih obveza, iako su neki od mogućih uzroka ove pojave objašnjeni u trećem poglavlju.

Udio prihoda od poreza i prireza porezu na dohodak u prihodima poslovanja (pdoh_tp) ukazuje na sposobnost prikupljanja prihoda iz vlastitih izvora lokalne jedinice - tj. njezin fiskalni kapacitet. Općenito, fiskalni kapacitet predstavlja jednu od mjera financijske stabilnosti lokalne jedinice pa veći fiskalni kapacitet rezultira manjim kreditnim rizikom (što potvrđuju i rezultati ekonometrijske analize). Odnos neto operativnog salda i prihoda poslovanja (nos_tp) također je negativno koreliran s kreditnim rizikom jer veći neto operativni saldo ukazuje na višak prihoda nad rashodima poslovanja. Omjeri otplate duga i gotovine (od_got) te neto financijskih obveza i prihoda poslovanja ( $\left.n f f_{-} t p\right)$ ukazuju na opterećenost dugom, tj. redom na sposobnost servisiranja (otplate) anuiteta duga gotovinom i na mogućnost financiranja viška financijskih obveza nad financijskom imovinom iz redovitih aktivnosti (prihodima poslovanja). Veće vrijednosti ovih pokazatelja ukazuju na veću izloženost dugu pa je logično da njihovim porastom raste i vrijednost kreditnog rizika. Konačno, odnos izravnog duga i prihoda poslovanja (id_tp) odražava sposobnost financiranja izravnog duga prihodima poslovanja no predznak koeficijenta za ovaj pokazatelj i nije sasvim logičan, tj. očekivao se upravo suprotan predznak s obzirom da veći udio duga u prihodima poslovanja treba rezultirati i većim kreditnim rizikom.

\subsection{ODNOS STVARNIH I PREDVIDENIH VRIJEDNOSTI KREDITNOG RIZIKA}

S ciljem ispitivanja prilagodbe modela kreditnog rizika lokalnih jedinica, vrijednosti default_proxy varijable (aproksimacije kreditnog rizika, tj. omjera dospjelih nepodmirenih $\mathrm{u}$ ukupno dospjelim obvezama) usporedit će se s onim predviđenima tobit modelom za obe karakteristike političke

\footnotetext{
${ }^{14}$ Faktor prilagodbe će biti bliži vrijednosti I što je manje opažanja za koje je $Y_{i}=\mathrm{O}$ (ne postoji kreditni rizik lokalne jedinice, tj. jednak je nuli). U promatranom uzorku za 23,56\% lokalnih jedinica aproksimirani kreditni rizik jednak je nuli.

${ }^{15}$ Granični učinak se može izračunati i na način da se umjesto evaluacije u aritmetičkim sredinama eksplanatornih varijabli, najprije izračuna za svaku vrijednost eksplanatornih varijabli u uzorku, a zatim aritmetička sredina dobivenih vrijednosti. Vrijednost graničnog učinka eksplanatorne varijable u tom slučaju gotovo je jednaka vrijednosti danoj u tablici 6.
} 
strukture izvršne vlasti (politika $=\{0, I\})$. Za svaku vrijednost varijable od interesa, zadane su vrijednosti varijabli $p d o h \_t p, n o s \_t p, n f l \_t p, o d \_g o t$ i id_tp. Predviđene vrijednosti za default_proxy izračunate su korištenjem relacije (Wooldridge, 2006)

$$
\hat{Y}_{i}=E\left[Y_{i} \mid X=X_{i}\right]=\Phi\left(\frac{\beta^{\prime} X_{i}}{\sigma}\right) \cdot \beta^{\prime} X_{i}+\sigma \cdot \phi\left(\frac{\beta^{\prime} X_{i}}{\sigma}\right),
$$

izračunate u procijenjenim vrijednostima odgovarajućih koeficijenata.

Imajući u vidu činjenicu da je granični učinak udjela prihoda od poreza na dohodak u prihodima poslovanja u Tobit modelu daleko najveći, a uz to je i raspon frekvencija ove varijable prilično širok (od 2,78 do 77,48\%), moguće vrijednosti udjela prihoda od poreza na dohodak u prihodima poslovanja podijeljene su u ro ekvidistantnih kategorija. Za svaku kategoriju udjela prihoda od poreza na dohodak u prihodima poslovanja postoje poduzorci stvarnih i predviđenih vrijednosti default_proxy varijable za koju je izračunata srednja vrijednost i medijan u odgovarajućem poduzorku. Na taj se način omogućava grafički prikaz moći predikcije Tobit modela. Grafikon I prikazuje stvarne i predviđene vrijednosti prosječnog kreditnog rizika lokalnih jedinica. Varijabla def_proxy označava prosjek opaženih vrijednosti za aproksimaciju kreditnog rizika unutar pojedinih kategorija. Varijable prilagođen_def_proxy_vlast i prilagođen_def_proxy označavaju - Tobit modelom - predviđene vrijednosti kreditnog rizika izračunate u srednjim vrijednostima utvrđenih odrednica u slučaju kompatibilnosti i inkompatibilnosti političke strukture izvršne vlasti na lokalnoj i državnoj razini.

\section{GRAFIKON I.}

Stvarne i predviđene vrijednosti prosječnog kreditnog rizika lokalnih jedinica

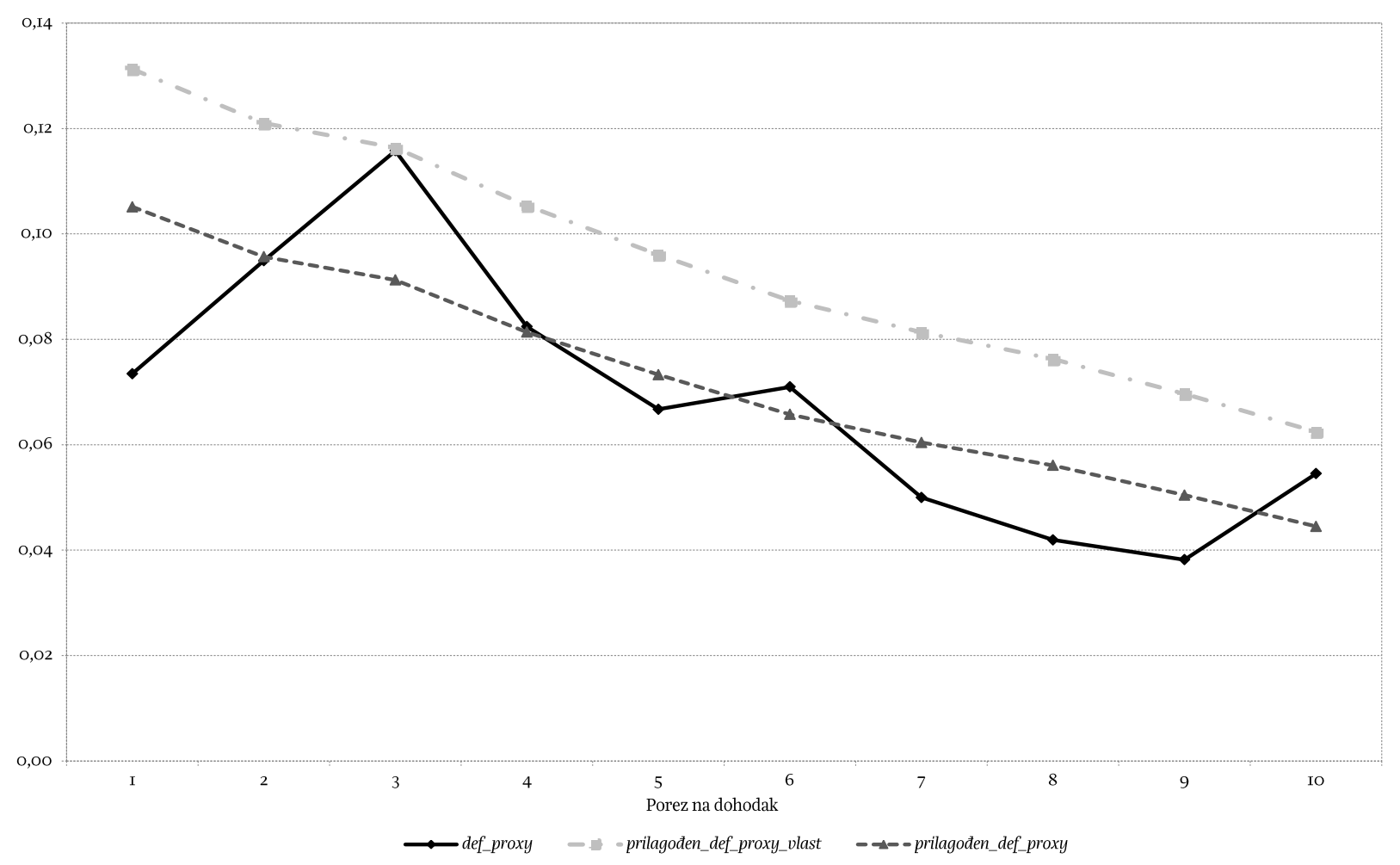

Izvor: Izračun autora. 
Očekivane vrijednosti kreditnog rizika u slučaju političke kompatibilnosti izvršne vlasti na lokalnoj i državnoj razini (tablica 6) su - u prosjeku - iznad opaženih vrijednosti default_proxy varijabli za sve kategorije udjela prihoda od poreza na dohodak u prihodima poslovanja. U slučaju političke inkompatibilnosti izvršne vlasti, situacija je znatno drugačija - očekivane vrijednosti kreditnog rizika za Tobit model uglavnom fluktuiraju oko postojećih default_proxy vrijednosti. ${ }^{16}$

\section{TABLICA 6.}

Unutar-uzorački test moći predikcije u srednjoj vrijednosti.

\begin{tabular}{|c|c|c|c|c|c|c|}
\hline $\mathbf{K}$ & $\mathbf{N}$ & default_proxy & $\mathbf{A}$ & $\mathbf{B}$ & $\mathbf{G}$ & $\mathbf{D}$ \\
\hline I & $2 \mathrm{I}$ & 0,0735 & O,I3I3 & O,IO5I & $0, \mathrm{I} 348$ & O,IO77 \\
\hline 2 & 30 & 0,0949 & O,I2IO & 0,0957 & 0,1237 & 0,0976 \\
\hline 3 & $6 I$ & O,II58 & O,II63 & o,o913 & 0,1226 & 0,0965 \\
\hline 4 & 78 & 0,0824 & O,IO54 & $\mathrm{O}, 08 \mathrm{I} 4$ & O,IO6I & 0,0817 \\
\hline 5 & IO5 & 0,0667 & O,096I & o,0733 & O,IOI2 & 0,0773 \\
\hline 6 & 92 & 0,07IO & 0,0873 & 0,0658 & 0,0892 & 0,0669 \\
\hline 7 & 68 & 0,0500 & 0,0813 & 0,0604 & 0,0800 & 0,0590 \\
\hline 8 & 60 & 0,0419 & 0,0763 & 0,056I & o,0793 & 0,0584 \\
\hline 9 & 37 & $\mathrm{O}, \mathrm{O} 382$ & 0,0697 & O,0504 & 0,0697 & 0,0503 \\
\hline IO & 4 & 0,0545 & 0,0625 & 0,0445 & 0,0584 & O,O4II \\
\hline
\end{tabular}

Napomena: $\mathrm{K}$ - kategorije udjela poreza na dohodak; $\mathrm{N}$ - broj opažanja; $\mathrm{A}$ - predviđanje za default_proxy $\hat{\mathrm{Y}}_{i}(\overline{\mathrm{X}}$, politika $=\mathrm{I}) ; \mathrm{B}-$ predviđanje za default_proxy $\hat{Y}_{i}(\bar{x}$, politika $=0) ; C-$ predviđanje za default_proxy $\hat{Y}_{i}(m$, politika $=1) ; D-$ predviđanje za default_proxy $\hat{Y}_{i}(m$, politika $=0)$. Izvor: Izračun autora.

\section{ZAKLJUČAK}

U Hrvatskoj znanstvenoj i stručnoj literaturi nisu istražene odrednice kreditnog rizika lokalnih jedinica. Zakonodavni okvir ne dopušta stečaj lokalnih jedinica u Hrvatskoj, što otežava istraživanje njihovog kreditnog rizika. U radu se, određuje mjera aproksimacije kreditnog rizika (engl. default proxy) lokalnih jedinica kao omjer dospjelih nepodmirenih u ukupno dospjelim obvezama u pojedinom razdoblju, na temelju čega se kvantificira postojeći kreditni rizik lokalnih jedinica. S obzirom na obilježja zavisne varijable (default_proxy) odabire se i odgovarajuća metoda za procjenu parametara modela. Tobit modelom dokazan je utjecaj političke kompatibilnosti izvršne vlasti na lokalnoj i državnoj razini, udjela prihoda od poreza na dohodak u prihodima poslovanja, omjera neto-operativnog salda i prihoda poslovanja, neto financijskih obveza i prihoda poslovanja, te izravnog duga i prihoda poslovanja, kao i otplate duga i gotovine na kreditni rizik lokalnih jedinica.

Glavno ograničenje istraživanja je nepostojanje povijesnih podataka o stečaju lokalnih jedinica, kojeg bi trebala odražavati binarna varijabla. Umjesto opažene binarne varijable (koja bi omogućila procjenu kreditnog rizika primjenom logit ili probit modela) koristila se zamjenska varijabla (default_proxy) koja je tek aproksimacija kreditnog rizika, a poprima kontinuirane vrijednosti u intervalu [o,I]. Osim toga,

\footnotetext{
${ }^{16}$ Prema izračunu autora potpuno analogni zaključci dobivaju se u slučaju analize moći predikcije tobit modela baziranih na vrijednosti medijana $m$.
} 
nisu javno dostupni podaci o čimbenicima kreditnog rizika lokalnih jedinica poput institucionalnog okvira, ekonomske strukture, upravljanja i administracije. U budućim istraživanjima treba ispitati utjecaj drugih nezavisnih varijabli na kreditni rizik lokalnih jedinica te riješiti problem zavisne varijable. Problem zavisne varijable mogao bi se riješiti na način da se utvrdi kritična vrijednost predložene aproksimacije kreditnog rizika na temelju koje bi se lokalne jedinice mogle kategorizirati u rizičnu skupinu čime bi se zavisna varijabla mogla izravno opaziti i poprimiti binarne vrijednosti. Buduća istraživanja mogla bi testirati utjecaj spomenutih pokazatelja na kreditni rizik lokalnih jedinica primjenom drugih metoda - po mogućnosti iz domene umjetne inteligencije.

Predloženi model procjene kreditnog rizika lokalnih jedinica mogao bi se dodatno unaprijediti. Međutim, ovim se radom prvi puta proučava kreditni rizik lokalnih jedinica u Hrvatskoj pa on može biti dobra početna točka za daljnja istraživanja. Osim toga, dobiveni rezultati mogli bi poslužiti Ministarstvu financija pri izdavanju jamstava i davanju odobrenja za zaduživanje lokalnim jedinicama te za analizu fiskalnih rizika. Modelom procijenjeni kreditni rizik lokalnih jedinica mogao bi poslužiti i kao dobra osnova za izračun zahtijevanog prinosa na obveznice lokalnih jedinica te kamatnih stopa na njihove kredite. 


\section{Prilog I.}

OSNOVNE ODREDNICE KREDITNOG RIZIKA LOKALNIH JEDINICA

\section{TABLiGaAi.}

Najčešće korišteni indikatori rejting agencije Standard \& Poor's

I. Ekonomija

I.I. Demografska struktura

Stanovništvo (ukupno i kao \% ukupnog)

Stope rasta stanovništva

Staro i mlado stanovništvo (kao \% ukupnog)

I.2. Ekonomska struktura

BDP (nominalni)

BDP (proizvodnja) i distribucija zaposlenih po sektorima

Stope zaposlenosti i nezaposlenosti

Zaposlenost kod najvećih poslodavaca

I.3. Bogatstvo

BDP po stanovniku

BDP po stanovniku kao \% nacionalnog ili regionalnog prosjeka (npr. EU-27)

I.4. Mogućnost rasta

Rast realnog BDP-a

Izvoz kao \% BDP-a i rast izvoza

Rast investicija

\section{Podrška i predvidivost}

2.I. Predvidivost

2.2. Uravnoteženost prihoda i rashoda

2.3. Transparentnost i odgovornost

2.4. Fiskalna politika

2.5. Izvanredna podrška

\section{Upravljanje i institucionalni okvir}

3.I. Sofisticiranost upravljanja

3.2. Institucionalni legitimitet

\section{Financijska fleksibilnost}

4.I. Zakonodavna ograničenja

4.2. Politička ograničenja

4.3. Ograničena fleksibilnost zbog planirane potrošnje

4.4. Ostali potencijalni pritisci i jednokratni prihodi

Autonomni prihodi kao \% prihoda poslovanja

Kapitalni rashodi kao \% ukupnih rashoda

Rashodi za zaposlene kao \% rashoda poslovanja

Rast rashoda poslovanja

Rast prihoda poslovanja

\section{Proračun}

Operativni saldo kao \% prihoda poslovanja Saldo nakon kapitalnih rashoda kao \% ukupnih prihoda

Saldo nakon zaduživanja kao \% ukupnih prihoda

6. Likvidnost i upravljanje dugom

6.I. Analiza likvidnosti Gotovina i likvidna imovina kao \% otplate duga Gotovina, likvidna imovina i krediti kao \% otplate duga Dug koji dospijeva unutar I2 mjeseci kao \% likvidne imovine i kredita Gotovina i likvidna imovina kao \% rashoda poslovanja Višak gotovine (prije kamata) kao \% rashoda za kamate Obveze kao \% ukupnih rashoda Potraživanja kao \% ukupnih prihoda

6.2. Upravljanje dugom Struktura duga Primjena izvedenica

\section{Teret duga}

Izdaci za kamate kao \% prihoda poslovanja

Otplata duga kao \% prihoda poslovanja Izravni dug kao \% prihoda poslovanja Neto izravni dug kao \% prihoda poslovanja Neto (porezom pokriveni) dug kao \% konsolidiranih prihoda poslovanja

Neto financijske obveze kao \% konsolidiranih prihoda poslovanja Izravni dug kao \% lokalnog BDP-a

Ukupan lokalni dug kao \% ukupnih lokalnih prihoda Ukupan dug (s jamstvima) kao \% prihoda poslovanja

\section{Izvanbilančne obveze}

8.I. Financijsko zdravlje javnih poduzeća

8.2. Kvazi-vladini programi

8.3. Javno-privatno partnerstvo

8.4. Spašavanje privatnih poduzeća

Izvor: Sistematizacija autora na temelju Standard \& Poor's (2007). 
TABLIGAA2.

Najčešće korišteni indikatori rejting agencije Moody's

\begin{tabular}{|c|c|}
\hline I. Poslovno okruženje & 5. Dug \\
\hline BDP po stanovniku & Ukupan izravni i neizravni dug (nominalni) \\
\hline Volatilnost BDP-a & Neto izravni i neizravni dug (nominalni) \\
\hline Indeks učinkovitosti Vlade & Neto izravni i neizravni dug po stanovniku \\
\hline 2. Institucionalni okvir & Neto izravni i neizravni dug kao \% BDP-a \\
\hline Predvidljivost, stabilnost i odgovornost & $\begin{array}{l}\text { Neto izravni i neizravni dug kao \% prihoda } \\
\text { poslovanja }\end{array}$ \\
\hline Fiskalna fleksibilnost (vlastiti izvori prihoda) & Neto izravni i neizravni dug kao \% ukupnih prihoda \\
\hline Fiskalna fleksibilnost (potrošnja) & Izravni dug u stranoj valuti kao \% izravnog duga \\
\hline Fiskalna adekvatnost (zaduživanje) & Kratkoročni izravni dug kao \% izravnog duga \\
\hline 3. Upravljanje & $\begin{array}{l}\text { Kratkoročni izravni dug i dugoročni izravni dug s } \\
\text { varijabilnom kamatnom stopom kao \% izravnog duga }\end{array}$ \\
\hline Fiskalno upravljanje & $\begin{array}{l}\text { Prosječno ponderirano dospijeće izravnog duga } \\
\text { (u godinama) }\end{array}$ \\
\hline Investicije i upravljanje dugom & 6. Financije \\
\hline Transparentnost i objavljivanje podataka & Diskrecijski vlastiti prihodi kao \% prihoda poslovanja \\
\hline Institucionalni kapacitet & Pomoći iz proračuna kao \% prihoda poslovanja \\
\hline 4. Gospodarska osnova & Namjenski prihodi kao \% prihoda poslovanja \\
\hline BDP po stanovniku & Izdaci za kamate kao \% prihoda poslovanja \\
\hline Stanovništvo (u tisućama) & Otplata duga kao \% ukupnih prihoda \\
\hline BDP (nominalni) & Obračunski saldo kao \% ukupnih prihoda \\
\hline BDP po stanovniku & Novčani saldo kao \% ukupnih prihoda \\
\hline $\begin{array}{l}\text { BDP po stanovniku kao \% nacionalnog } \\
\text { prosjeka }\end{array}$ & $\begin{array}{l}\text { Bruto potrebe za zaduživanjem kao \% ukupnih } \\
\text { prihoda }\end{array}$ \\
\hline BDP po stanovniku (PPP) & Ukupni rashodi po stanovniku (nominalni) \\
\hline Realni BDP (\% promjene) & Ukupni rashodi kao \% BDP-a \\
\hline Nezaposlenost (\%) & Primarni saldo kao \% prihoda poslovanja \\
\hline \multirow[t]{6}{*}{ Nacionalna nezaposlenost (\%) } & Bruto operativni saldo kao \% prihoda poslovanja \\
\hline & Neto operativni saldo kao \% prihoda poslovanja \\
\hline & Stupanj samofinanciranja \\
\hline & Kapitalni izdaci kao \% ukupnih rashoda \\
\hline & $\begin{array}{l}\text { Razlika složene (petogodišnje) godišnje stope rasta } \\
\text { ukupnih prihoda i ukupnih rashoda (\%) }\end{array}$ \\
\hline & Neto obrtni kapital kao \% ukupnih rashoda \\
\hline
\end{tabular}

Izvor: Sistematizacija autora na temelju Moody's (2008). 
TABLIGA A3.

Najčešće korišteni indikatori rejting agencije Fitch Ratings

\begin{tabular}{ll}
\hline I. Institucionalni okvir & 3. Financije \\
\hline Odnosi među administrativnim cjelinama & Analiza prihoda \\
\hline Centralizacija/decentralizacija & Analiza rashoda \\
\hline Struktura prihoda & Kretanje operativne i tekuće marže \\
\hline Sustav fiskalnog izravnanja & Stanje rezervi \\
\hline $\begin{array}{l}\text { Fleksibilnost financijskih aranžmana lokalne } \\
\text { jedinice sa središnjom državom }\end{array}$ & Likvidnost \\
\hline Vrsta odgovornosti lokalne jedinice & 4. Upravljanje i administracija \\
\hline Usmjerenost na ulaganje ili poslovanje & Institucionalne politike \\
\hline Javne funkcije u nadležnosti lokalne jedinice & Proračunske prakse \\
\hline Pravni okvir & Financijsko izvještavanje i računovodstvo \\
\hline Stupanj autonomije & Političko, porezno i radno okruženje \\
\hline Nefleksibilnost izdataka & Prihodna i rashodna ograničenja \\
\hline Potražnja za kapitalnim ulaganjima & 5. Gospodarstvo \\
\hline Snaga institucionalnog okvira & Glavni pokretači gospodarstva \\
\hline 2. Dug i dugoročne obveze & Zaposlenost \\
\hline Pokazatelji zaduženosti i trendovi & Dohodak i bogatstvo \\
\hline Buduće potrebe za kapitalom i dugom & Ostali demografski čimbenici \\
\hline Struktura duga & Porezno opterećenje \\
\hline Financiranje mirovina i sličnih naknada & \\
\hline Neizravni rizici i potencijalne obveze & \\
\hline-0 & \\
\hline
\end{tabular}

Izvor: Sistematizacija autora na temelju Fitch Ratings (2010). 


\section{Prilog 2.}

\section{POTENCIJALNE ODREDNICE KREDITNOG RIZIKA LOKALNIH JEDINICA U HRVATSKOJ}

\section{TABLIGA A4.}

Inicijalni skup nezavisnih varijabli obuhvaćenih istraživanjem

\begin{tabular}{|c|c|c|}
\hline Br. & Varijabla & Opis varijable \\
\hline I. & status & $\begin{array}{l}\text { Binarna varijabla koja poprima vrijednost I ukoliko lokalna jedinica ima status } \\
\text { grada, a o ukoliko ima status općine }\end{array}$ \\
\hline 2. & politika & $\begin{array}{l}\text { Binarna varijabla koja poprima vrijednost i ukoliko je ista politička stranka } \\
\text { na vlasti u državi i lokalnoj jedinici, u protivnom je o }\end{array}$ \\
\hline 3. & izvoz_BDP & Omjer vrijednosti izvoza i BDP-a lokalne jedinice \\
\hline 4. & LBDP_NBDP & Omjer lokalnog i nacionalnog BDP-a po stanovniku \\
\hline 5. & BDP_st & Lokalni BDP po stanovniku lokalne jedinice \\
\hline 6. & lst_nst & Omjer broja stanovnika lokalne jedinice i ukupnog broja stanovnika Hrvatske \\
\hline 7. & une_lst & Udio nezaposlenih stanovnika u ukupnom stanovništvu lokalne jedinice \\
\hline 8. & $v p \_t p$ & $\begin{array}{l}\text { Udio vlastitih prihoda (prihoda od poreza i administrativnih pristojbi) u prihodima } \\
\text { poslovanja }\end{array}$ \\
\hline 9. & pom_tp & Omjer pomoći i prihoda poslovanja \\
\hline IO. & pdoh_tp & Udio prihoda od poreza na dohodak u prihodima poslovanja \\
\hline II. & nos_tp & Omjer neto operativnog saldai prihoda poslovanja \\
\hline 12. & $t r \_t p$ & Omjer rashoda poslovanja i prihoda poslovanja \\
\hline 13. & $t p \_u p$ & Udio prihoda poslovanja u ukupnim prihodima \\
\hline I4. & ur_up & Omjer ukupnih rashoda i ukupnih prihoda \\
\hline 15. & nok_ur & Omjer neto obrtnog kapitala i ukupnih rashoda \\
\hline I6. & ur_st & Ukupni rashodi po stanovniku lokalne jedinice \\
\hline 17. & ur_BDP & Omjer ukupnih rashoda i BDP-a lokalne jedinice \\
\hline 18. & $k i \_k o$ & Omjer kratkotrajne imovine i kratkoročnih obveza \\
\hline 19. & got_tr & Omjer gotovine i rashoda poslovanja \\
\hline 20. & od_tp & Omjer otplate duga i prihoda poslovanja \\
\hline $2 \mathrm{I}$. & od_got & Omjer otplate duga i gotovine \\
\hline 22. & id_ui & Omjer izravnog duga i ukupne imovine \\
\hline 23. & $i d \_t p$ & Omjer izravnog duga i prihoda poslovanja \\
\hline 24. & $n f l \_t p$ & Omjer neto-financijskih obveza i prihoda poslovanja \\
\hline 25. & id_BDP & Omjer izravnog duga i BDP-a lokalne jedinice \\
\hline 26. & id_st & Izravni dug po stanovniku lokalne jedinice \\
\hline 27. & id_up & Omjer izravnog duga i ukupnih prihoda \\
\hline
\end{tabular}

Napomena: Vrijednost BDP-a lokalnih jedinica za sve pokazatelje aproksimirana je na temelju broja stanovnika lokalne jedinice i BDP per capita županije u kojoj se lokalna jedinica nalazi.

Izvor: Prikaz autora. 


\section{TABLIGA A5.}

Korelacijska matrica zavisne varijable i odabranih eksplanatornih varijabli

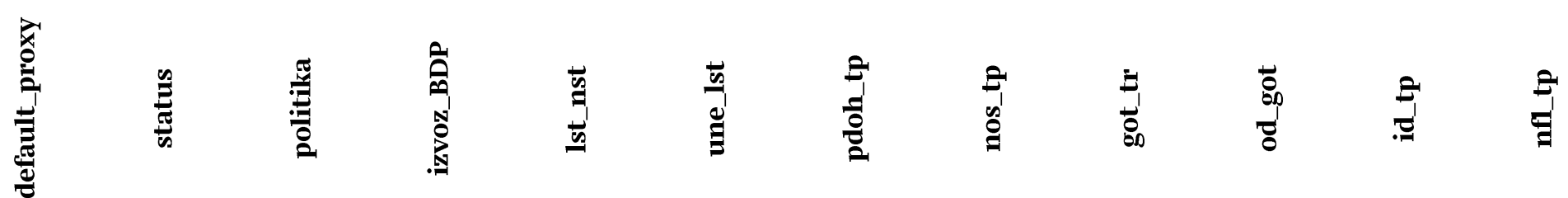

\begin{tabular}{|c|c|c|c|c|c|c|c|c|c|c|c|c|}
\hline default_proxy & I,OOOO & & & & & & & & & & & \\
\hline status & -o,IO33 & I,OOOO & & & & & & & & & & \\
\hline politika & O,IO54 & $-0,065 \mathrm{I}$ & I,OOOO & & & & & & & & & \\
\hline lst_nst & $-0,0606$ & 0,2495 & $-0,0555$ & 0,0636 & I,OOOO & & & & & & & \\
\hline une_lst & 0,0058 & $-0,0356$ & O,I5OI & $-0,0921$ & -0,04I6 & I,OOOO & & & & & & \\
\hline nos_tp & $-0,1753$ & $-0,0320$ & 0,0253 & 0,0498 & 0,0178 & $-0,0270$ & $-0,0294$ & I,OOOO & & & & \\
\hline got_tr & $-0,0287$ & -O,I957 & 0,0854 & $-0,055 \mathrm{I}$ & $-0,0607$ & $-0,0416$ & $-0,0844$ & 0,3346 & I,OOOO & & & \\
\hline od_got & o,0350 & $-0,0174$ & -0,0199 & o,oI66 & -0,0137 & $-0,0847$ & $-0,086 \mathrm{I}$ & 0,0567 & -O,I292 & I,OOOO & & \\
\hline$i d \_t p$ & 0,0265 & 0,2642 & $-0,0751$ & 0,0720 & 0,0576 & -O,IOIO & o,o816 & $-0,0577$ & $-0,0639$ & 0,08I4 & I,OOOO & \\
\hline$n f l \_t p$ & 0,0963 & 0,2347 & $-0,0823$ & o,0639 & o,0626 & $-0,0277$ & 0,IOO3 & $-0,2436$ & $-0,6232$ & $-0,0352$ & 0,6289 & I,OOOO \\
\hline
\end{tabular}

Izvor: Izračun autora. 


\section{LITERATURA}

Altman, E. I., 1968. "Financial Ratios, Discriminant Analysis and the Prediction of Corporate Bankruptcy”. The Journal of Finance, 23 (4), 589-609. doi: 10.IIII/j.I540-6261.1968.tboo843.x

Anderson, R., 2007. The Credit Scoring Toolkit. Oxford: Oxford University Press.

Baesens, B. [et al.], 2003. "Using neural network rule extraction and decision tables for credit-risk evaluation”. Management Science, 49 (3), 312-329. doi: 10.1287/mnsc.49.3.312.12739

Bajo, A. i Primorac, M., 2009. “Zašto je lokalnim jedinicama potreban kreditni rejting?". Riznica, (7), 3340.

Bajo, A. i Primorac, M., 2010. „Local government borrowing practice in Croatia”. Financial Theory and Practice, 34 (4), 379-406.

Barati-Stec, I., 2004. The practice of Municipal infrastructure Finance in Hungary. Budapest: Modeling Municipal Investment Activity.

Benson, E., Marks, B. i Raman, K., 1984. "State regulation of accounting practices and municipal borrowing costs". Journal of Accounting and Public Policy, 3 (2), 107-122. doi: 10.1016/02784254(84)90003-6

Capeci, J., 1991. "Credit risk, credit ratings and municipal bond yields: A panel study". National Tax Journal, 44 (4), 4I-56.

Capeci, J., I994. "Local fiscal policies, default risk, and municipal borrowing costs". Journal of Public Economics, 53 (I), 73-89. doi: 10.1016/0047-2727(94)900I4-O

Carleton, W. T. i Lerner, E. M., 1969. "Statistical Credit Scoring of Municipal Bonds". Journal of Money, Credit and Banking, I (4), 750-764. doi: 10.2307/1991449

Garnevale, R. i Coulton, B., 20o6. Rating Subnationals Above the Sovereign in the Euro Area - A FineTuning. Fitch Ratings - International Public Finance (Criteria Report). New York, NY: Alacra Store

Chatterjee, S. i Barcun, S., 1970. "A nonparametric approach to credit screening". Journal of the American Statistical Association, 65 (329), 50-154. doi: I0.1080/0I62I459.1970.10481068

Cox, G. W. i McCubbins, M. D., 1986. "Electoral Politics as a Redistributive Game". Journal of Politics, 48, 370-389. doi: $10.2307 / 2131098$

Dixit, A. i Londregan, J., 1996. "The determinants of success of special interests in redistributive politics". The Journal of Politics, 58 (4), II32-II55. doi: 10.2307/2960152

Ederington, H. L., 1985. „Classification models and bond ratings“. Financial Review, 20 (4), 237-262.

Fisher, L., 1959. „Determinants of risk premiums on corporate bonds“. Journal of Political Economy, 67 (3), $217-237$.

Fitch Ratings, 2010. "International Local and Regional Governments Rating Criteria”. International Public Finance - Sector-Specific Criteria Report, March 17.

Gaillard, N., 2009. "The Determinants of Moody's Sub-Sovereign Ratings". International Research Journal of Finance and Economics, Issue 3I.

Gentry, J. A., Whitford, D. T. i Newbold, P., 1988. „Predicting industrial bond ratings with a probit model and funds flow components“. Financial Review, 23 (3), 269-286. doi: IO.IIII/j.I5406288.1988.tboI267.x

Greene, W. H., 20o8. Econometric Analysis. New York: Prentice-Hall, Inc.

Hájek, P. i Olej, V., 2006. "Modeling Municipal Rating by Cluster Analysis and Neural Networks". Proceedings of the 7th WSEAS International Conference on Neural Networks, Cavtat, Croatia, June I2-I4, pp. 73-78.

Hájek, P. i Olej, V., 2007. "Modeling Municipal Creditworthiness by Hierarchical Structures or Fuzzy Inference Systems". Proceedings of the 6th WSEAS International Conference on Artificial Intelligence, Knowledge Engineering and Data Bases, Corfu Island, Greece, February I6-I9.

Hastie, K. L., 1972. "Determinants of Municipal Bond Yields". The Journal of Financial and Quantitative Analysis, 7 (3), 1729-1748. doi: $10.2307 / 2329798$

Henley, W. E. i Hand, D. J., 1996. "A k-Nearest-Neighbour Classifier for Assessing Consumer Credit Risk". The Statistician, 45 (I), 77-95. doi: $10.2307 / 2348414$

Huang, Z. [et al.], 2004. „Credit rating analysis with support vector machines and neural networks: a market comparative study“. Decision Support Systems, 37 (4), 543-558. doi: Io.IoI6/SoI679236(O3)00086-I

Ingram, R. i Copeland, R., 1982. "Municipal market measures and reporting practices: An -extension". Journal of Accounting Research, 20 (2), 766-772. doi: $\underline{10.2307 / 2490900}$ 
Jackson, J. D. i Boyd, J. W., 1988. „A statistical approach to modeling the behavior of bond raters“. The Journal of Behavioral Economics, I7 (3), 173-193. doi: 10.1016/0090-5720(88)90008-3

Lewis, B. L., Patton, J. M. i Green, S. L., 1988. "The Effects of Information Choice and Information Use on Analysts' Predictions of Municipal Bond Rating Changes". The accounting Review, 63 (2), 270-282.

Lindbeck, A. i Weibull, J., 1987. "Balanced budget redistribution and the outcome of political competition”. Public Choice, 52 (3), 273-297. doi: 10.1007/BFooII6710

Lipnick, L. H., Rattner, Y. i Ebrahim, L., 1999. „The Determinants of Municipal Credit Quality“. Government Finance Review, (12), 35-4I.

Liu, L. i Tan, K. S., 2009. „Subnational Credit Ratings: A Comparative Review“. Policy Research Working Paper. Washington: The World Bank.

Min, J. H. i Lee, Y.-C., 2005. "Bankruptcy prediction using support vector machine with optimal choice of kernel function parameters". Expert Systems with Applications, 28 (4), 603-614. doi: I0.1016/j.eswa.2004.12.008

Moody's, 2008. "Regional and Local Governments Outside the US: Updated Rating Methodology". Moody's International Public Finance - Regional and Local Governments, May.

Odom, M. i Sharda, R., 1990. "A neural networks model for bankruptcy prediction". Proceedings of the IEEE International Conference on Neural Network, (2), I63-168.

Ohlson, J. A., 1980. „Financial Ratios and the Probabilistic Prediction of Bankruptcy“. Journal of Accounting Research, I8 (I), I09-I3I. doi: $10.2307 / 2490395$

Ong, G. S., Huang, J. J. i Tzeng, G. H., 2005. "Building credit scoring models using genetic programming". Expert Systems with Applications, 29, 4I-47. doi: 10.1016/j.eswa.2005.01.003

Peterson, E. G., 1998. Measuring Local Government Credit Risk and Improving Creditworthiness. Washington: The World Bank.

Peterson, E. G., 20oo. Building Local Credit Systems. Washington: The World Bank.

Piramuthu, S., 1999. „Financial Credit Risk Evaluation with Neural and Neuro-Fuzzy Systems“. European Journal of Operational Research, II2 (2), 310-321.

Raman, K. K., 198I. „Financial Reporting and Municipal Bond Rating Changes”. The Accounting Review, 56 (4), 910-926.

Shin, K. S. i Han, I., 1999. „Case-based reasoning supported by genetic algorithms for corporate bond rating“. Expert Systems with Applications, I6 (2), 85-95. doi: 10.IOI6/So957-4I74(98)00063-3

Shin, K. S. i Lee, Y. J., 2002. "A genetic algorithm application in bankruptcy prediction modeling". Expert Systems with Applications, 23 (3), 32I-328. doi: 10.10I6/Sog57-4174(02)0005I-9

Standard \& Poor's, 2007. "Criteria: Rating International Local And Regional Governments: A Primer". Ratings Direct, March 7.

Wallace, W., 198I. "The association between municipal market measures and selected financial reporting practices". Journal of Accounting Research, I9 (2), 502-520. doi: 10.2307/2490877

Wang, J., Wang, S. i Lai, K. K., 2005. "A New Fuzzy Support Vector Machine to Evaluate Credit Risk". IEEE Transactions on Fuzzy Systems, I3 (6), 779-786. doi: IO.IIog/TFUZZ.2005.859309

West, R. R., 1970. „An alternative approach to predicting corporate bond ratings“. Journal of Accounting Research, 8 (I), II8-125. doi: $\underline{10.2307 / 2674717}$

Wooldridge, J. M., 2002. Econometric Analysis of Cross Section and Panel Data. Cambridge, MA: MIT Press.

Wooldridge, J. M., 20o6. 'Introductory Econometrics. New York: Thomson South-Western.

Zakon o stečaju, NN 44/96. Zagreb: Narodne novine.

Zmijewski, M. E., 1984. „Methodological Issues Related to the Estimation of Financial Distress Prediction Models“. Journal of Accounting Research, 22, 59-82. doi: $\underline{10.2307 / 2490859}$ 